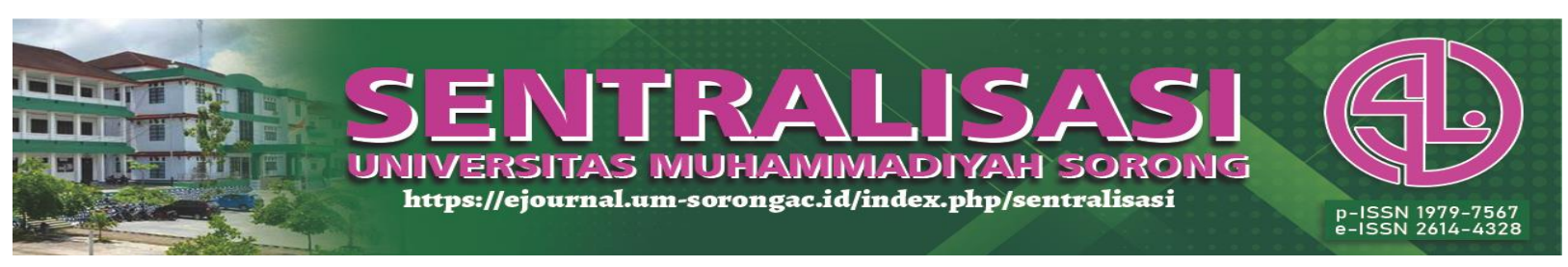

\title{
Analysis Of The Impact Of Tourist Visit Level On The Economy Of Local Communities In The Village Of Bena Village, Ngada District
}

\author{
Maria Endang Jamu ${ }^{1}$, Yulius Laga ${ }^{2}$ \\ 1,2 Program Studi Manajemen, Universitas Flores, Indonesia \\ E-mail : endangjamu2@gmail.com
}

direvisi: 04/12/2020 dipublikasikan: 31/01/2021

\begin{abstract}
Abstrak. Kampung tradisional Bena sudah menjadi tujuan wisata di kabupaten Ngada dan merupakan ikon wisata yang diakui secara nasional, bahkan dikenal secara global. Kampung tradisional ini ramai dikunjungi oleh para wisatawan karena keunikan yang dimiliki. Adapun tujuan dari penelitian ini adalah untuk menganalisis dampak dari adanya kunjungan wisatawan pada ekonomi masyarakat lokal di kampung tradisional Bena. Pendekatan yang digunakan dalam penelitian ini adalah kualitatif deskripstif, dengan metode pengumpulan data adalah wawancara secara mendalam (in-depth interview). Informan dalam penelitian ini adalah masyarakat lokal yang ada di sekitar area wisata. Hasil penelitian menunjukkan bahwa peningkatan jumlah kunjungan wisatawan telah membawa dampak yang positif bagi masyarakat lokal di kampung tradisional Bena,yang diantaranya adalah adanya peningkatan pendapatan ekonomi masyarakat dari hasil penjualan tenunan yang dibeli wisatawan, adanya kesempatan kerja di bidang pariwisata, adanya peluang usaha bagi masyarakat lokal, adanya pekerjaan sampingan bagi masyarakat lokal selain sebagai petani, dan kesejahteraan masyarakat yang semakin membaik dari tahun ke tahun.
\end{abstract}

Kata kunci: Dampak Ekonomi, Wisatawan, Mayarakat Lokal, Desa Wisata

\begin{abstract}
The traditional village of Bena has become a tourist destination in the Ngada district and is a nationally recognized tourist icon, even known globally. This traditional village is visited by many tourists, because of its uniqueness. The purpose of this research is to analyze the impact of tourist visits on the economy of lokal communities in the traditional village of Bena. This is important to be researched and analyzed because, the increasing interest of tourists, who come to visit the traditional village, has a positive impact, especially on the lokal economy. The approach used in this research is descriptive qualitative, with the data collection method is in-depth interviews. The informants in this study were lokal people around the tourist area. The results show that the increase in the number of tourist visits has had a positive impact on the lokal community in Bena Village, which includes an increase in community income from the sale of woven products, employment opportunities in tourism, business opportunities for lokal people, and side jobs. apart from being a farmer, and people's welfare which is getting better from year to year.
\end{abstract}

Keywords : Economic Impact, Tourists, Lokal Communities, Tourism Village

\section{Introduction}

Tourism is one of the country's foreign exchange earning sectors so that it has an important role in Indonesia's development. The existence of the tourism sector has provided positive benefits for the government, the private sector, the public who are directly involved in these tourism activities (Swantara \& Darsana, 2017 ; Ardianti, 2017; Anisah \& Riswandi, 2015). The existence of large and continuous tourist visits to a tourist spot will have an impact on the economic life of the community, either directly or indirectly. (Prasetyo \& Suryoko, 2018; (Achadiat Dritasto, IR. \& Anggraeni, 2013 ; Josephine et al., 2015 ; Windayani \& Sri Budhi, 2017 ; Febriana \& Pangestuti, 2018 ; Choiriyah, 2017 ; Wuri, 2015 ; Urbanus \& Febianti, 2017 ) 


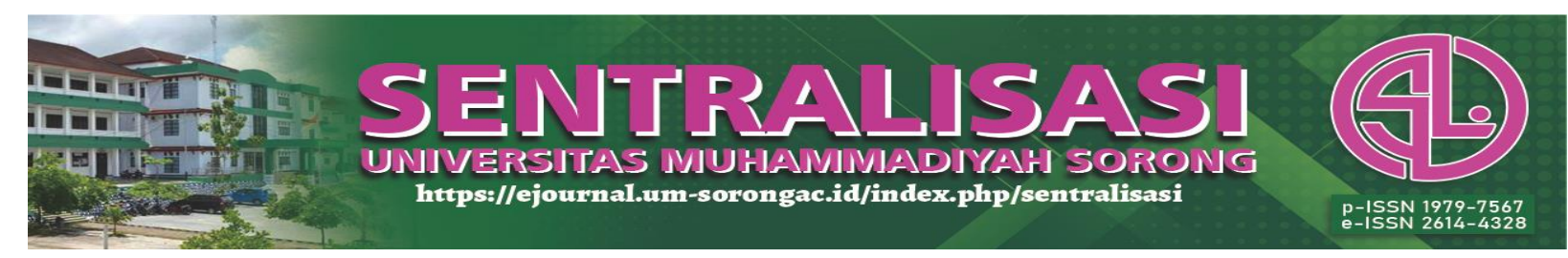

In research as stated by Hamzah \& Hermawan (2018) several impacts of tourism on the local economy include : (1) Impact on community income; (2) Impact on employment opportunities; (3) Impact on prices; (4) Impact on the distribution of benefits; (5) Impact on ownership and control; (6) Impact on development in general; (7) Impact on government revenue. Also, Sudarmayasa \& Lanang Nala (2019) in their study said that tourism should provide a lot of income for regions that are aware of its potential. The community is expected to have the awareness to take advantage of this potential which will ultimately have an impact on local communities. People who maintain and preserve their culture will become one of the main attractions for tourists.

The traditional village of Bena was chosen as the research location because based on data from Ngada in Figures (2018) there was a significant increase in the number of tourist visits in Ngada Regency from 2015 to 2018 . Bena traditional village is one of the tourist villages that still maintain authenticity and preserves culture. Locally, this can be seen from the shape of the houses of residents who still use lontar as the main ingredient in building houses. The traditional village of Bena is still in the first position as a tourist attraction visited by many tourists, compared to other traditional villages such as Luba traditional village, Tololela traditional village, Gurusina traditional village, Wogo traditional village, Bela traditional village. This data shows that the tourist interest in visiting the traditional village of Bena is very high compared to the traditional village which is also in the same sub-district.

Based on previous studies which suggest that the success of tourism activities is when the tourism activities can improve the welfare of the local community. According to Hary (2016) tourism will be considered a failure if the economic benefits are not felt by local communities, but are enjoyed by outsiders or foreign investors. Based on this statement, this study aims to analyze the impact of tourist visits on the economy of local communities in the traditional village of Bena. This is also important to research, because based on the data on the number of visitors, the traditional village of Bena is one of the tourist destinations that is being visited by tourists in recent years. The number of tourist visits according to Husaen (2012) is one indicator to measure the success of a tourism industry which will have an impact on local communities and local government.

\section{Research Method}

The research design used is descriptive qualitative, with data collection methods namely in-depth interviews (in-depth interviews). The informants in this study were local people in the traditional village of Bena. Interviews were conducted with twenty people who were also weavers, ticket officers also as caretakers in the tourist village of the traditional village of Bena. In addition to collecting data through in-depth interviews, direct observation was also carried out by researchers in order to complement the information obtained.

The data analysis technique uses the data triangulation technique, which starts from the first stage, namely data collection, the second stage is data reduction, the third stage is data display and 


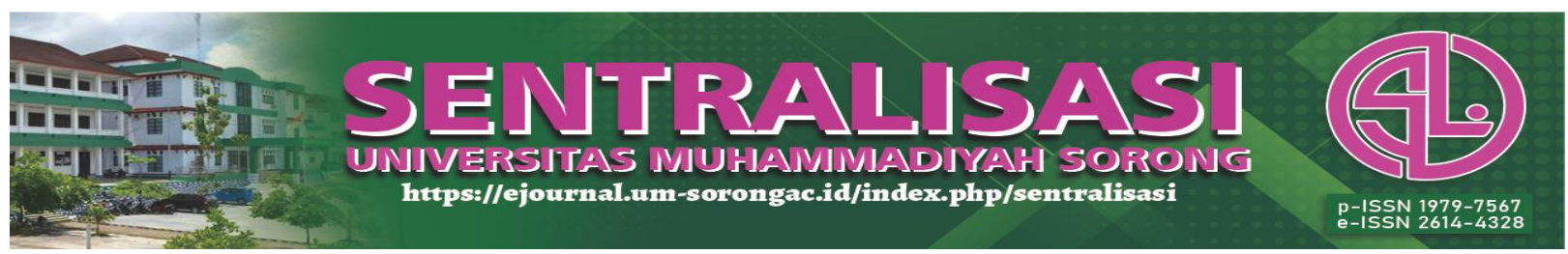

the last stage is the conclusion or data verification. In the first stage, data collection was carried out by researchers, namely through in-depth interviews with informants who were also local people who lived around tourist objects. In addition to in-depth interviews, researchers also made direct observations at the research location. After all the information is obtained, the next step is data reduction, which in this stage, the researcher listens to all the interview results from the informants and rewrites them in writing or script so that they can determine the themes made in tabular form as the data to be analyzed. After deciding the theme, the next step is to display data, namely the theme that has been determined by the researcher and then processed and analyzed. at the last stage of data analysis, namely concluding, from the data that have been made by the researcher, to be able to answer research questions in the introductory section.

\section{Result dan Discussion}

Ngada Regency has local wisdom that has been approved both nationally and internationally. One of the most famous is the traditional village of Bena. The traditional village of Bena has become a nationally recognized icon, even globally known, and has become a tourist destination in Ngada district. This traditional village is visited by many tourists, both domestic and foreign tourists, because of the uniqueness of this traditional village. One of the uniqueness of this traditional village is the traditional form of houses, which are also their respective custom homes. The people in the traditional village of Bena are still very determined to defend their traditional houses made of lontar.

Over time, in 2015 the traditional village of Bena began to be known and visited by many tourists, both local and foreign tourists. The increasing number of tourist visits from year to year will certainly have an impact on local communities around the tourist area. To obtain information regarding the impact felt by the local community with the visit of tourists to the traditional village of Bena, researchers conducted in-depth interviews with twenty informants, of whom the informants were local people in the traditional village of Bena.

\section{Informant responses regarding the impact of tourist visit rates on the local economy}

In order to obtain responses from local communities in the traditional village of Bena, in depth interview was conducted with 20 informants. Based on the results of the interview, a summary of the responses was obtained as in the following table:

Table 1. Summary of Interview Results

\begin{tabular}{ll}
\hline No & \multicolumn{1}{c}{ Statement } \\
\hline 1 & Tourist visits have a positive impact on the local economy. \\
2 & Tourist visits have had a positive impact, namely in terms of the welfare of local \\
& communities.
\end{tabular}




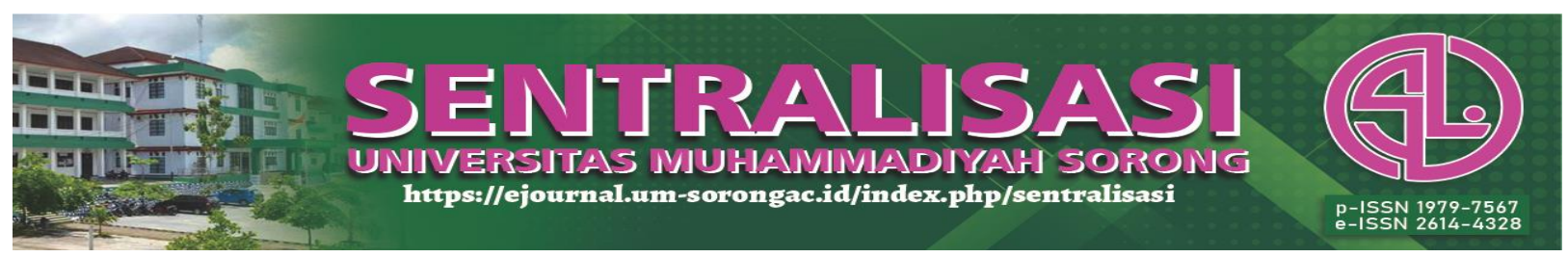

3

A tourist visit to the traditional village of Bena provides the opportunity to have a side job.

4 The existence of tourist visits to the traditional village of Bena provides business opportunities for weaver mothers.

5 A tourist visit to the traditional village of Bena provides an opportunity for weaver mothers to be more creative in producing quality weaving.

6 The large number of tourists visiting has an impact on the sale of entrance tickets and helps the local community's annual activities in the traditional village of Bena.

Source: Processed by researchers, 2020

\section{The impact of the level of tourist visits on the economy of local communities in the traditional village of Bena}

The increase in tourist visits as described in the background section has had a positive impact on the economic life of local communities in the traditional village of Bena. This can be seen from the results of interviews with twenty informants as a whole saying that tourist visits have had a positive and significant impact on the lives of the people of the traditional village of Bena, most of the impacted on the local economy.

"We, the people here, are very grateful for the visits of tourists, well ... if we all spent time in the garden, now we are mostly in the village waiting for tourists because they will definitely go around our house and buy the shawls we have woven, they Those who came did not come home empty, they must have bought our shawls. Almost all the mothers here are weavers. And all of them have already felt the impact, because tourists must buy our products. So the money we sell can be used to increase our needs. We were mothers, sometimes we couldn't have lunch because there were too many visitors. Almost all people here feel the impact of tourists in our traditional village". (R.01)

Similar research has also been conducted by (Nuhung et al., 2013; Nur et al., 2018) where the results of the study show that tourist visits to certain areas where there is the involvement of local communities have had a positive impact, especially in terms of the economy. The community feels the economic impact because of their involvement in maintaining and preserving the uniqueness and beauty that exists in their respective areas.

The impact of the level of tourist visits on business opportunities for weavers in the traditional village of Bena

The visit of tourists to the traditional village of Bena has brought changes to the behavior of the local people there. Previously, almost all of them only worked as farmers helping their husbands in the garden, but since the increasing number of visits to this traditional village, mothers have started to change their behavior patterns. Mothers began to spend their time at home to open businesses, starting from selling their weavings, in the form of scarves, sarongs, bracelets, and other handicrafts. In addition, there are also people who open a business in the form of a kiosk selling people's needs in the traditional village of Bena as well as the needs of tourists who come to visit. 


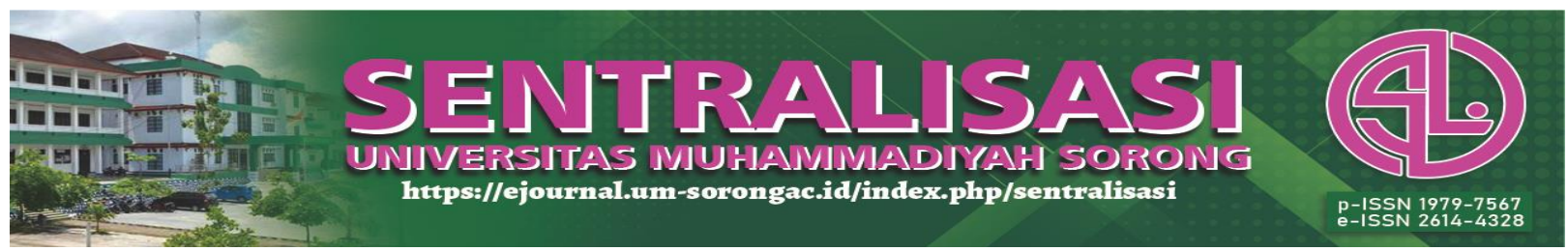

Mothers began to be creative in producing woven products that were sold to tourists. Another change is that six years ago, only a part of them focused on weaving and the products were sold to a market which is quite far from the traditional village of Bena, so that the motivation of mothers was also low in producing large quantities of weaving. As in the following interview excerpt:

"There are some that have been of woven for a long time, but we sell them to the market, far from here, Mother. Sometimes it's a long way still no one is selling, and our competitors are many mothers, the price they bargain for is also low. But since many have come to our village, and they buy our weaving products, we make a lot, and we sell them from our respective homes. You see, almost all the people's houses here have a display of the weaving in front of their houses. Later, tourists will come and have a look and buy them if they like. So we mothers are excited to want to weave in large quantities because we know that there will be tourists who buy it. "( R.5)

The presence of tourists and the high demand for weaving products have provided opportunities for local people to produce more and more quality woven fabrics, as well as providing lodging in the community of Bena village for tourists who want to stay longer there.

This course has a positive impact on the local economy. As seen in the following interview excerpt: "It was a high impact, mom, their bought our scarves. In 2018 and 2019, I also got the results I got from selling scarves to tourists who came to this traditional village of Bena. We can increase our income, the people here, mother “. (R.12)

The impact of tourist visits to the traditional village of Bena has been felt by local people who come directly involved with tourists, especially in terms of selling their weaving products. As in the following interview excerpt: "Their influence comes, mothers who have weaving spend more time in the village to make weaving, then display it in front of the house yard, and tourists who pass by will buy it" (R.7). The results of a similar study were also conducted by Hiariey \& Sahusilawane (2013), wherein visits of tourists visiting Natsepa Beach have opened business opportunities for the surrounding community, example, the community provides various kinds of tourist needs.

\section{Impact of the level of tourist visits on ticket sales and assisting the annual activities of local communities in the traditional village of Bena}

The impact of increasing tourist visits from year to year has been feeling by people in the traditional village of Bena. One of the impacts is to help of a cultural festival which is held once a year which is often known as "Reba". The "Reba" festival is a ceremony of gratitude and respect for the ancestors of the Ngada community which is mandatory for all Ngada people to carry out and is carried out once a year. Reba celebration combines cultural and religious rituals. This traditional party is also held in the traditional village of Bena.

To hold this annual event requires a lot of money, at least the community must provide a certain amount of money. The amount of money is not small of course with a background of work, most of whom are farmers. However, since this traditional village is crowded with tourists, the community no longer feels burdened by the event, because part of the ticket money is allocated for traditional events so that the society only adds a small amount. As in the following interview excerpt: "Every year there is a rebha here. So the rebha event is if there are residents who want to build 


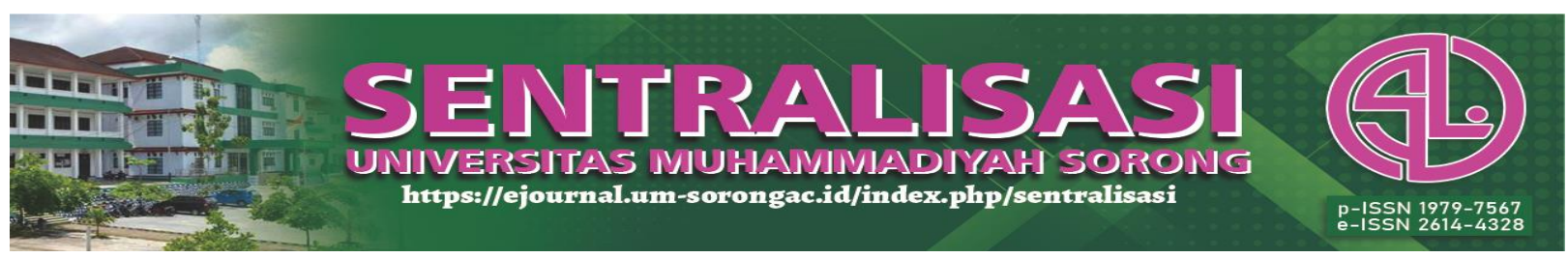

their traditional house which is also their residence. That is for the rebha program, the money that must be prepared is twenty million mothers if you make a new house, if only about fifteen million renovations. Fortunately, now the community is being assisted, so we only prepare rice and a small amount of money, while most of the managed funds have been prepared for this budget. So we feel grateful and very much helped by Bena's getting to be known and visited by many tourists "(R.12)

The interview excerpt above shows that the presence of tourists has had a positive influence on the lives of local people in the traditional village of Bena. Local people feel the impact of tourist visits in their area. Most of the proceeds from the sale of tickets or admission tickets for tourists are allocated for the cultural festival "rebha" which is held once a year and requires a large amount of money or budget. With the sale of admission tickets, the community feels a very significant impact from tourist visits in the traditional village of Bena. Similar research results were also conducted by Suastika \& Yasa (2017) the results of their research showing that the presence of tourists has had a positive impact on the community around the tourist area. people who are directly involved in tourism activities can directly relate to the impact of these tourism activities.

\section{The impact of the level of tourist visits on the welfare of the local community in the traditional village of Bena}

Tourism activities that are in direct contact with the community, of course, will have an impact directly or indirectly on local communities around the tourist area of Oktaviyanti (2013). A similar thing is felt by local people who live in the traditional village of Bena. The high number of tourists who come to visit the traditional village of Bena has a positive impact on the welfare of the people there.

The results of the sale of weaving directly have an impact on the community's economy and the people's welfare are getting better. Almost all mothers in the traditional village of Bena have felt the impact of the presence of tourists. They compete to produce quality weavings at affordable prices, thus making tourists buy their weavings. The income from selling weaving has been able to make them have a better life than before. As in the following interview excerpt: "The economy of the people here has been better in the last five years, mom. Mothers feel it the most because some of the mothers here weave. I just saw that every house has a woven display. They sell the weaving to tourists and increase their income " (R.20)

Apart from selling woven products, local people also get other benefits from the presence of tourists in the traditional village of Bena, namely the rental fee for tourists who choose to stay at local people's homes. There are foreign tourists who visit who choose to stay more than 1 day in the traditional village of Bena, thus having an impact on the community there. Tourists will be direct to stay at local residents' homes, and the cost of lodging will be immediately received by the community and used to increase their income. Since this traditional village was very crowded, most people have felt the impact, namely tourists staying at their homes.

"Foreign guests can stay at a community house. Divide 2 buildings and it takes turns. Let people feel fair. Later, foreign tourists will pay directly at the building for lodging costs. The money is for those whose 


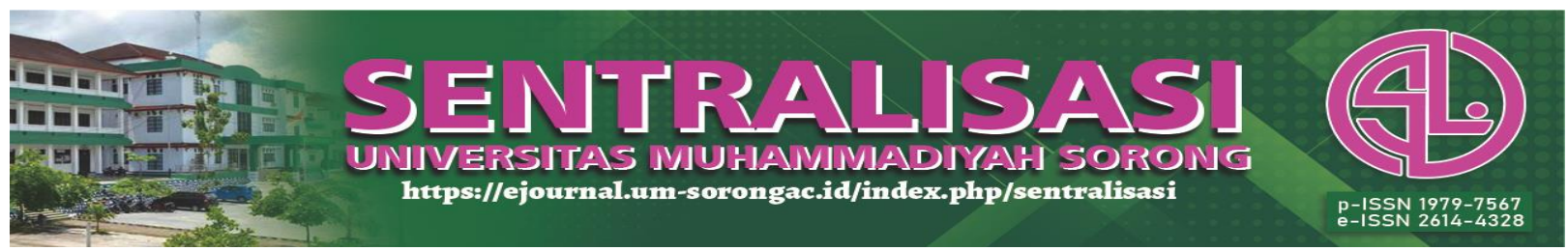

houses are staying. Eat what is provided by the community. And all buildings will get a turn later for foreign guests to stay if someone wants to stay. It could be foreign tourists who often live overnight. so the mother is not bad enough to increase our income " (R. 18)

It can be seen that the local community's economy is getting better from year to year. The life of the people in the traditional village of Bena is better than in previous years. it can seem from the increasing income of the community from the sale of weaving whose is also the product of the weaving of the women in the traditional village of Bena. Apart from income obtained from woven products, other income that is also obtained by the community is from lodging fees for foreign guests. The results of a similar study were also conducted by Ernawati (2011), which stated that the presence of tourists has had a positive impact on the communities around the tourist area.

\section{The impact of the level of tourist visits on the opportunities for local people to have additional jobs}

The impact of tourist visits is not only on changes in the economy of local communities. Having a side job apart from being a farmer since the crowd of tourist visits has been felt by local people in the traditional village of Bena. The people who initially had the main job as farmers, now have side jobs as weavers, ticket officers, and have their businesses. People who used to spend time in the garden are now mostly in Bena village to meet tourists who want to buy their weavings. In addition to that, some people are involved in helping work in the tourism sector as ticket officers who at certain times will get wages from their work. "Their influence comes, mothers who have weaving spend more time in the village to make weaving, then display it in front of the house yard, and tourists who pass by will buy " (R.10)

Research conducted (Shantika \& Mahagangga, 2018; Abdillah et al., 2016) said that in its development tourism activities will have an impact on the economy of the surrounding community directly or indirectly. The existence of tourist visits can have a big impact on local communities, one of which is the transfer of local people from their previous jobs and becoming workers in tourism. This also happened in the village of Bena. People who initially were farming, switched or focused on being in the village awaiting the arrival of tourists who would later go around and buy their weavings. The results of the sale of the weaving have had a positive impact on the local economy. Also, the presence of tourists makes local people involved as tourism workers, namely to become officers selling entrance tickets for tourists. As in the following interview excerpt: " feels the difference, before the traditional village of Bena, many people visited, we people spent a lot of time in the garden taking care of the produce. But now we are mostly in the village to weave. If we used to weave we went to sell in the market, now we weave and sell in this village. Because their tourists will go around people's houses and if there is something they like our shawl they buy. Thankfully there are two to 3 pieces of scarves bought by tourists. I am grateful because from the proceeds from selling the shawl, I can support my three children alone without my husband, who has been traveling for a long time and has not returned home. But I can pay their school fees with the proceeds from selling weaving to tourists" (R.02) 


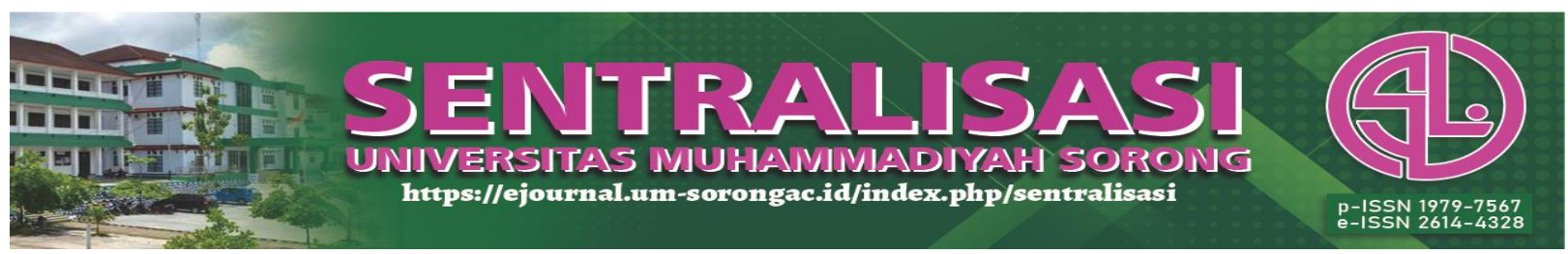

The interview quotes above show that the presence of tourists in the community of the traditional village of Bena has had a positive impact on the local community's economy. The results of a similar study conducted by (Hary, 2016 Hermawan, 2017; Aryunda, 2011; Martina, 2014; Hamzah \& Hermawan, 2018; Purwanti \& Dewi, 2014) concluded that tourism activities have had a positive impact on local communities, directly or indirectly. The direct impact includes an increase in sales turnover, an increase in community income, an increase in community welfare, an increase in income for people who work in the tourism sector, an increase in entrepreneurial opportunities, an increase in community control of their tourist villages, and an increase in government revenue through tourist fees.

\section{Conclusion}

Based on the results of interviews and processed interview results, several conclusions were obtained including; 1) The presence of tourists has had a positive impact on the lives of local people, especially in terms of income. 2) The life of the local community has improved in the last five years. 3) The interest in tourist visits to the traditional village of Bena which is getting higher every year has had a positive impact on the local community. What used to be that mothers spent a lot of time in their gardens, now it has changed more time in the village to weave and sell their weaving products to visiting tourists. 4) The presence of tourists also provides opportunities and opportunities for the community to be involved in tourism activities. Local people have a side job apart from farming, being ticket attendants also weaving.

The presence of tourists has had a positive impact on the local community in the traditional village of Bena. Therefore, the Regional Government, in this case, is the Ngada Regency Tourism Office, needs to further improve existing facilities and infrastructure around the tourist area, in addition to improving the promotion and facilitating local communities in improving skills such as English language skills, innovation in producing products that can be offered to tourists besides weaving and other positive activities.

\section{Acknowledgement}

The researchers' gratitude goes to the Ministry of Research, Technology and Higher Education who has funded this research activity, as well as the Head of the Institute for Research and Community Service, University of Flores, Head of the National Unity, Politics and Community Protection Agency of Ngada Regency, local communities in the traditional village of Bena and enumerators who have helped expedite activity data

\section{References}

Abdillah, A., Hamid, D., \& Topowijono, T. (2016). DAMPAK PENGEMBANGAN PARIWISATA TERADAP KEHIDUPAN MASYARAKAT LOKAL DI KAWASAN WISATA (Studi Pada Masyarakat Sekitar Wisata Wendit, Kabupaten Malang). Jurnal Administrasi Bisnis S1 Universitas Brawijaya, 30(1), 74-78.

Achadiat Dritasto, IR., M., \& Anggraeni, A. A. (2013). Analisis Dampak Ekonomi Wisata Bahari. 


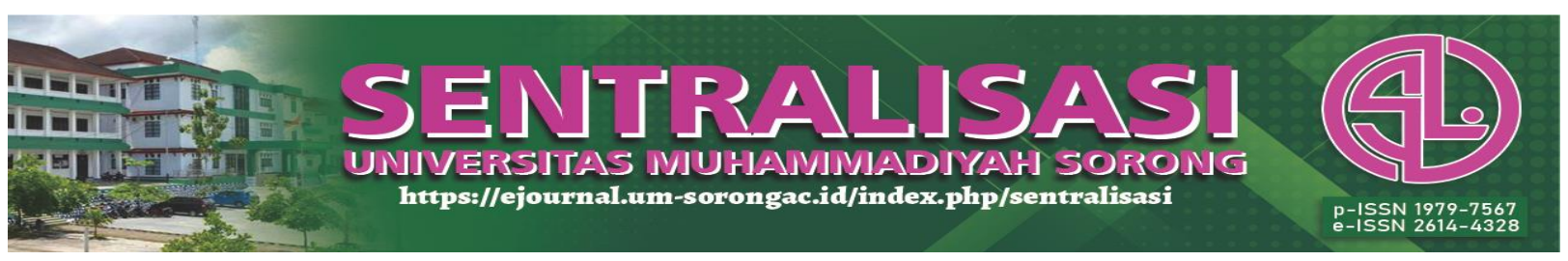

Reka Loka, xx(x), 1-8.

Angka, N. D. (2018). Kabupaten NGADA DALAM ANGKA.

Anisah \& Riswandi. (2015). Pantai Lampuuk dan Dampaknya Terhadap Perekonomian Masyarakat. Jurnal Ekonomi Dan Kebijakan Publik Indonesia, 2(2), 69-82.

Ardianti, S. (2017). Pengaruh Kunjungan Wisata Terhadap Pendapatan Masyarakat Di Desa Medewi, Kecamatan Pekutatan, Kabupaten Jembrana Tahun 2012-2015. Jurnal Pendidikan Ekonomi Undiksha, 9(1), 198. https://doi.org/10.23887/jjpe.v9i1.20005

Aryunda, H. (2011). Dampak Ekonomi Pengembangan Kawasan Ekowisata Kepulauan Seribu. Journal of Regional and City Planning, 22(1), 1. https://doi.org/10.5614/jpwk.2011.22.1.1

Choiriyah, I. U. (2017). Dampak Sosial-Ekonomi Wisata Terhadap Masyarakat Lokal (Studi Pada Wisata Pemancingan Delta Fishing Sidoarjo). Prosiding Seminar Dan Call For Paper, 294-300.

Ernawati, N. M. (2011). PENGARUH PARIWISATA TERHADAP KEHIDUPAN SOSIAL BUDAYA PESISIR di Kawasan Taman Nasional Bali Barat dan Taman Wisata Pulau Menjangan. Sabda: Jurnal Kajian Kebudayaan, 6(1), 69. https://doi.org/10.14710/sabda.v6i1.13307

Febriana, Y. E., \& Pangestuti, E. (2018). ( Studi Pada Desa Wisata Gubugklakah Kecamatan Poncokusumo Kabupaten Malang. Jurnal Administrasi Bisnis (JAB), 61(4), 141-150.

Hamzah, F., \& Hermawan, H. (2018). Evaluasi Dampak Pariwisata Terhadap Sosial Ekonomi Masyarakat Lokal. Jurnal Pariwisata, 5(3), 195-202. http://ejournal.bsi.ac.id/ejurnal/index.php/jp

Hary, H. (2016). Dampak Pengembangan Desa Wisata Nglanggeran Terhadap Ekonomi Masyarakat Lokal. Jurnal Pariwisata, 3(2), 105-117.

Husaen, Hasan. 2012. Faktor-Faktor yang Mempengaruhi Keputusan Wisatawan Dalam Melakukan Kunjungan Wisata di Kota Tidore Kepulauan. Fakultas Ekonomi, Universitas Hasanuddin. h:1-15

Hermawan, H. (2017). Dampak Pengembangan Desa Wisata Nglanggeran Terhadap Ekonomi Masyarakat Lokal. III(2). https://doi.org/10.31219/osf.io/xhkwV

Hiariey, L. S., \& Sahusilawane, W. (2013). Dampak Pariwisata Terhadap Pendapatan Dan Tingkat Kesejahteraan Pelaku Usaha Di Kawasan Wisata Pantai Natsepa, Pulau Ambon. Jurnal Organisasi Dan Manajemen, Vol, 9(No, 1), 87-105.

Josephine, W., Hardanti, Y. R., \& Hartono, L. B. (2015). Kehidupan Ekonomi Dan Sosial Masyarakat. Wuri, Josephine Dkk, 2015, Dampak Keberadaan Kampung Wisata Terhadap Kehidupan Ekonomi Dan Sosial Masyarakat, 18(2), 143-156. https://doi.org/Jurnal Penelitian.

Martina, S. (2014). Dampak pengelolaan taman wisata alam kawah putih terhadap kehidupan sosial dan ekonomi masyarakat. Jurnal Pariwisata, I(2), 81-89.

Nuhung, M., Nuryana, I., \& Rasyid, N. (2013). Pengaruh Tingkat Kunjungan Wisatawan Terhadap Pendapatan Masyarakat Di Kawasan Wisata Tanjung Bayang Makassar Makassar. Jurnal Ekonomi Balance, 9(1), 123-141. https://doi.org/10.26618/jeb.v9i1.1863 


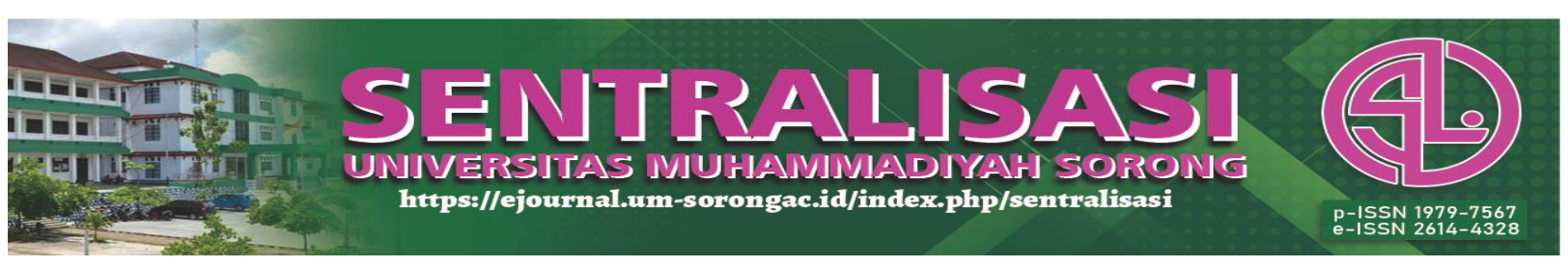

Nur, I., Mariantha, I. N., Syafri, \& Faridah. (2018). Implikasi pengembangan desa wisata terhadap peningkatan ekonomi masyarakat lokal (studi di Desa Pao). Seminar Nasional Dan Call for Paper: Manajemen, Akuntansi Dan Perbankan 2018, 1090-1104.

Oktaviyanti, S. S. (2013). Dampak Sosial Budaya Interaksi Wisatawan Dengan Masyarakat Lokal Di Kawasan Sosrowijayan. Dampak Sosial Budaya Interaksi Wisatawan Dengan Masyarakat Lokal Di Kawasan Sosrowijayan, 5(3), 201-208. https://doi.org/10.22146/jnp.6693.

Prasetyo, B., \& Suryoko, S. (2018). Dampak pengembangan pariwisata terhadap perkembangan umkm pada kawasan wisata Dieng. Journal Of Social And POliticlitic, 1-11.

Purwanti, N. D., \& Dewi, R. M. (2014). Pengaruh Jumlah Kunjungan Wisatawan Terhadap Pendapatan Asli Daerah Kabupaten Mojokerto Tahun 2006-2013. Jurnal Fakultas Ekonomi, Universitas Negeri Surabaya, 2(3), 1-12.

Shantika, B., \& Mahagangga, I. G. A. O. (2018). Dampak Perkembangan Pariwisata Terhadap Kondisi Sosial Ekonomi Masyarakat Di Pulau Nusa Lembongan. Jurnal Destinasi Pariwisata, 6(1), 177. https://doi.org/10.24843/jdepar.2018.v06.i01.p27

suastika, i, \& Yasa, I. (2017). Pengaruh Jumlah Kunjungan Wisatawan, Lama Tinggal Wisatawan Dan Tingkat Hunian Hotel Terhadap Pendapatan Asli Daerah Dan Kesejahteraan Masyarakat Pada Kabupaten/Kota Di Provinsi Bali. E-Jurnal Ekonomi Pembangunan Universitas Udayana, 6(7), 1332-1362.

Sudarmayasa, I. W., \& Lanang Nala, I. W. (2019). Dampak Keberadaan Sektor Pariwisata Terhadap Peningkatan Faktor Sosial Ekonomi Masyarakat Kampung Tenun Samarinda Di Kota Samarinda Kalimantan Timur. Jurnal Master Pariwisata (JUMPA), 05, 283. https://doi.org/10.24843/jumpa.2018.v05.i02.p04.

Swantara, I. K. B. P., \& Darsana, I. B. (2017). Pengaruh Kunjungan Wisatawan, Pendapatan PHR, dan Pendapatan Retribusi Obyek Wisata Terhadap PAD Kabupaten Gianyar. E-Jurnal EP Unud, 6(12), 2551-2582.

Urbanus, N., \& Febianti. (2017). Analisis dampak perkembangan pariwisata terhadap perilaku konsumtif masyarakat wilayah bali selatan. Jurnal Kepariwisataan Dan Hospitalitas, 1(No.2), 118-133.

Windayani, I., \& Sri Budhi, M. (2017). Pengaruh Kunjungan Wisatawan, Tingkat Hunian Hotel, Pengeluaran Wisatawan Terhadap Penyerapan Tenaga Kerja Dan Pertumbuhan Ekonomi Di Provinsi Bali. E-Jurnal Ekonomi Pembangunan Universitas Udayana, 6(2), 195-224.

Wuri, J. (2015). Dampak Keberadaan Kampung Wisata Terhadap Kehidupan Ekonomi Dan Sosial Masyarakat. Jurnal Penelitian, 18(2), 143-156. 